\title{
ТРАДИЦІЙНА СЕРПНЕВА ВЕБКОНФЕРЕНЦІЯ «УЧЕНІ НАЦІОНАЛЬНОЇ АКАДЕМІЇ ПЕДАГОГІЧНИХ НАУК УКРАЇНИ - УКРАЇНСЬКИМ ВЧИТЕЛЯМ»
}

\section{7-29 серпня 2019 р., м. Київ, Україна \\ https://doi.org/10.37472/2707-305X-2019-1-1-3-3}

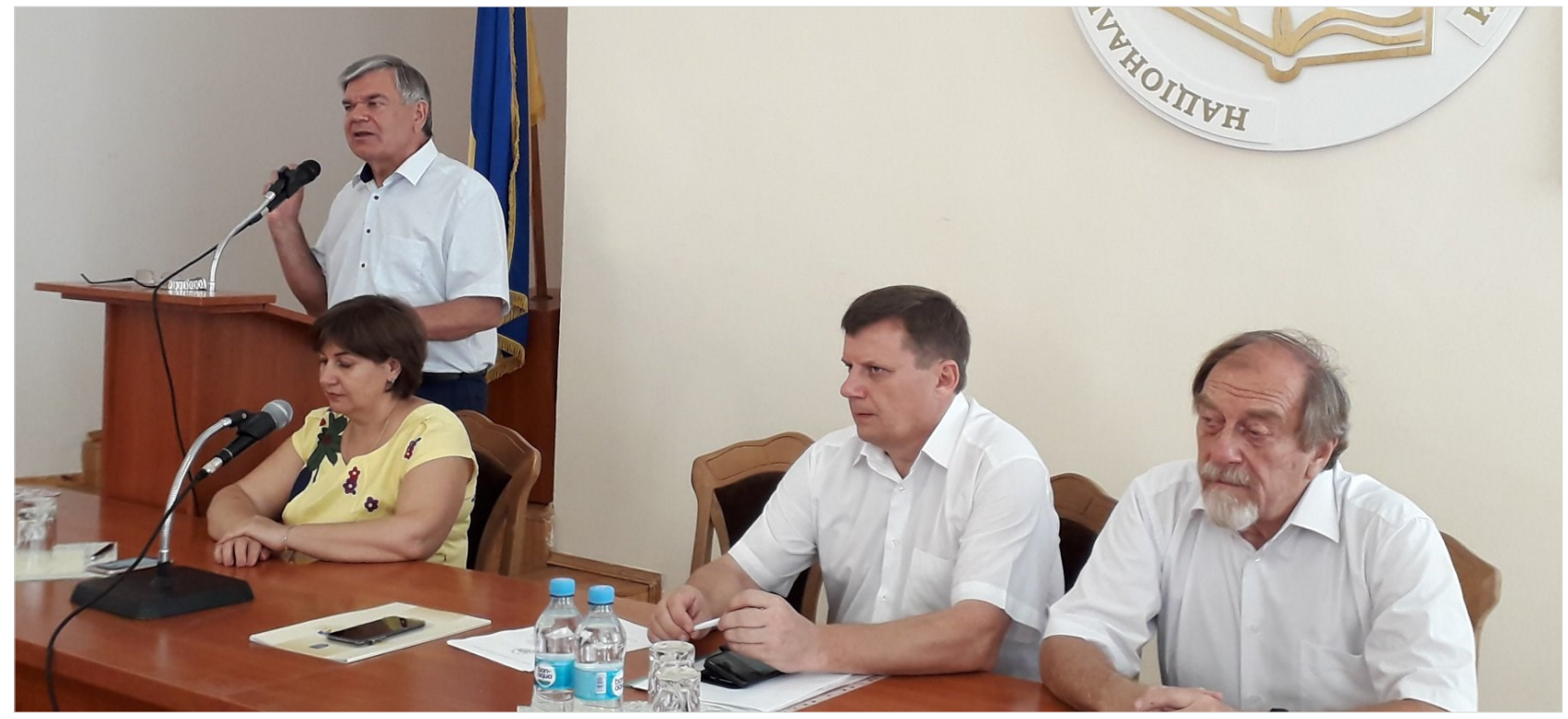

Упродовж трьох днів 27-29 серпня 2019 р. тривала традиційна онлайн конференція «Учені Національної академії педагогічних наук України українським вчителям», участь в які взяли науковці Інституту педагогіки , Інституту проблем виховання, Інституту спеціальної педагогіки і психології імені Миколи Ярмаченка, Інституту соціальної та політичної психології та Інституту інформаційних технологій і засобів навчання Національної академії педагогічних наук України.

Розпочав захід екс-заступник Міністра освіти і науки України Вадим Карандій, який подякував Національній академії педагогічних наук України за онлайн формат конференцій, що стали традиційними й очікуваними вчителями, оскільки це - один із засобів, що робить освітян єдиним колективом. Він привітав учасників і зазначив, що час серпневих нарад - це певний квест, коли освітяни ставлять перед собою нові цілі й визначають, як їх досягти. Вадим Карандій зазначив, що стратегія розвитку освіти України залишається незмінною - це Нова українська школа.

Президент НАПН України Василь Кремень привітав аудиторію і наголосив, що таке спілкування $€$ корисним і для працівників освіти, і для науковців, які доповідатимуть про результати досліджень у контексті практичних потреб учителя. Президент зауважив, що нині українська освіта у стані реалізації тих ідей, що десятиліттями розроблялися в Національній академії педагогічних наук України. Це і принцип людиноцентризму в освіті, й перехід до 12-річного навчання й профільної старшої школи й ін. Зміни було розпочато у 2000-му році й лише відоме волюнтаристське рішення 2010-го перекреслило й не дало можливості реалізувати інновації. «Ми вітаємо ті зміни, що відбуваються у школі. Безумовно, потрібно відслідковувати практичну реалізацію теоретично правильних принципів і 
вчасно коригувати освітню діяльність», - сказав Василь Кремень.

Під час онлайн конференцій були обговорені нові науково обґрунтовані рішення й поради, здобуті в ході наукових досліджень. А також, як завжди, розглядались й обговорювалися організаційні питання, що стосуються, зокрема, планування, ведення шкільної документації, навчально-методичного забезпечення тощо. । найголовніше - практичні поради щодо досягнення стратегічних завдань реформування освіти.

Основні завдання Інституту педагогіки НАПН України полягають у реалізації державної політики у сфері реформування загальної середньої освіти, у виконанні наукових досліджень й забезпеченні їх реального впливу на розвиток загальної середньої освіти. Суспільно значущими результатами наукової діяльності Інституту педагогіки НАПН України є концепції розвитку освіти, державні освітні стандарти, навчальні програми, підручники та інноваційні методики й технології навчання. Ученими Інституту педагогіки НАПН України до нового навчального року підготовлено понад 100 видань наукового, виробничо-практичного й навчального призначення. Найбільший відсоток становить (66 \%) навчальна література для закладів загальної середньої освіти, методична література (22 \%) для вчителів і студентів закладів вищої освіти, аспірантів і докторантів. Усі видання (їх електронні оригінал-макети) розміщено у вільному доступі на вебсайті Інституту педагогіки НАПН України.

Найбільш очікуваними були поради від науковців відділу початкової освіти Інституту педагогіки НАПН України щодо використання в освітньому процесі типової освітньої програми для 1 і 2 класів закладів загальної середньої освіти, розробленої під керівництвом О.Я. Савченко. Автори підручників й посібників для 2 класу: К.І. Пономарьова, О.Я. Савченко, В.О. Мартиненко, О.Ю. Прищепа, О.В. Вашуленко (з української мови); О.В. Онопрієнко, Н.П. Листопад (з математики); Н.М. Бібік, І.В. Андрусенко (з інтегрованого курсу «Я досліджую світ») надали методичні поради щодо особливостей організації освітнього процесу й роботи з навчальною літературою, особливу увагу приділяючи при цьому збалансованому вибору різних форм і прийомів навчання, які найбільш вмотивовують і зацікавлюють молодшого школяра, сприяють ефективному формуванню умінь і навичок, розвивають критичне мислення й самостійність дитини.

Зважаючи на те, що провідні ідеї Концепції Нової української школи мають втілюватися в усіх освітніх ланках, науковці Інституту педагогіки НАПН України надають методичні рекомендації щодо осучаснення змісту й методів навчання, а також апробують на випередження інноваційні підходи, які будуть закладені в основу нового стандарту основної школи та нової моделі старшої профільної школи. Зокрема, співробітники наукових відділів запропонували експериментальні методики навчання української мови і літератури на засадах діяльнісного, особистісно орієнтованого і компетентнісного підходів, що сприяють формуванню компетентнісного мовця й читача. Зосередили увагу на психологопедагогічних чинниках та дидактико-педагогічних умовах удосконалення процесу навчання української мови як другої (неспорідненої) для класів з мовами навчання національних меншин, а також на змісті, методах і прийомах навчання мов і літератур національних меншин на засадах компетентісного підходу.

Для вчителів, які викладають предмети математично-природничого циклу запропоновано методики компетентнісно орієнтованого навчання. Акцентовано увагу на діяльнісному складнику, організації експериментальної і проєктної діяльності учнів, їх цифровій й медіаграмотності, прийомах роботи з текстами й інфографікою. 3 метою забезпечення варіативності організації профільного навчання, задоволення освітніх потреб старшокласників і їх професійного самовизначення запропоновано програми спецкурсів.

Методичні рекомендації з предметів мистецької й здоров'язбережувальної галузей висвітили вчені Інституту проблем виховання НАПН України. Особливу увагу зосереджено на формуванні ціннісних орієнтацій учнів як свідомих громадян, їх патріотичності, вмінні аналізувати й аргументовано відстоювати власні позиції.

Учені Інституту спеціальної педагогіки і психології імені Миколи Ярмаченка НАПН України надали практичні поради щодо застосування методик комплексного психологопедагогічного супроводження дітей з особливими освітніми потребами, форм і методів навчання, технічних засобів. Під час виступів було розкритто теоретико-методологічні засади 
сучасних досліджень у галузі спеціальної педагогіки, корекційної педагогіки та спеціальної психології, зокрема, результати інноваційних досліджень у галузі лінгвістики й лінгводидактики української жестової мови; супровід педагогічних працівників щодо інтегрування дітей з особливими освітніми потребами до загальноосвітнього простору; алгоритм діагностики і технологій компенсації з урахуванням сучасних досягнень науки і практики.

Учені Інституту інформаційних технологій і засобів навчання НАПН України ознайомили педагогів 3 вітчизняним та закордонним досвідом використання інформаційнокомунікаційних технологій в освіті, зокрема 3 «Європейською стратегією щодо підтримки вчителів» (створення онлайнових спільнот і ресурсів для шкільних фахівців, включаючи нові можливості eTwinning для вчителів, онлайнмережі для вчителів на ранніх етапах кар'єри та для їх наставників; онлайн-курси (включаючи MOOC), обмін передовим досвідом серед тих, хто здійснює підготовку вчителів щодо застосу- вання Рамки цифрової компететності для підтримки професійного розвитку вчителів та здійснення ними самооцінювання.

у виступах учених Інституту соціальної та політичної психології НАПН України було висвітлено результати всеукраїнських репрезентативних опитувань, що проводяться в рамках моніторингу громадської думки щодо проблем освіти та заходів з їі реформування. Зазанчено, що переважна більшість громадян (73,9%) прагнуть освітніх реформ. При цьому 42,2 \% повністю або частково схвалюють напрям, у якому наразі розвивається вітчизняна освіта, 26,3 \% вважають напрям неправильним і майже третина (29,5 \%) не може дати чіткої відповіді 3 цього приводу. Однією з причин неоднозначного ставлення суспільства до освітніх реформ $є$ брак інформації про їхній зміст, цілі та етапність реалізації. Науковцями підготовлено рекомендації учителям щодо комунікаційних стратегій у діяльності закладів освіти.

Матеріали конференції можна переглянути за посиланням.

ЗАСЕКІНА Тетяна Миколаївна кандидат педагогічних наук, старший науковий співробітник, заступник директора з науково-експериментальної роботи Iнституту педагогіки Національної академії педагогічних наук України, м. Київ, Україна

TRADITIONAL AUGUST WEBCONFERENCE "THE NATIONAL ACADEMY OF EDUCATIONAL SCIENCES OF UKRAINE RESEARCHERS TO UKRAINIAN TEACHERS" August 27-29, 2019, Kyiv, Ukraine

Tetiana Zasiekina

PhD in Pedagogy, Senior Researcher, Deputy Director for Scientific and Experimental Work, Institute of Pedagogy of the National Academy of Educational Sciences of Ukraine, Kyiv, Ukraine

Abstract. The teacher conferences are traditionally held at the beginning of the school year. Scientists of the National Academy of Pedagogical Sciences of Ukraine conduct them online. During this event, topical issues of the organization of the educational process in the current academic year are discussed, and the results of scientific researches in the field of education are highlighted. This year, attention was paid to the implementation of the concept of "The New Ukrainian School", the modernization of the content of primary education, the features of new textbooks developed by the author teams of scientists. The implementation of education reform requires modern scientific and methodological and methodological support, which is provided by the sciences of education, pedagogy and psychology.

Keywords: online conference, guidelines, scientific research in education. 